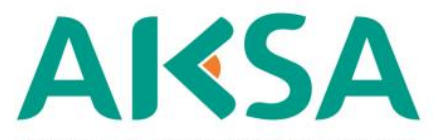

JURNAL DESAIN KOMUNIKASI VISUAL
AKSA: JURNAL DESAIN KOMUNIKASI VISUAL

ISSN: 2615-1111 (online)

Available online at:

http://aksa.stsrdvisi.ac.id

\title{
PENERAPAN TEORI GOLDEN SECTION PADA FOTO LANDSCAPE PANTAI DI GUNUNGKIDUL
}

\author{
Nofria Doni Fitri ${ }^{1}$, R. Hadapiningrani. $K^{2}$
}

${ }^{1}$ Sekolah Tinggi Seni Rupa dan Desain Visi Indonesia

${ }^{2}$ Sekolah Tinggi Seni Rupa dan Desain Visi Indonesia

E-mail: donifitri13@gmail.com

\begin{tabular}{|c|c|}
\hline ARTICLE INFO & ABSTRAK \\
\hline $\begin{array}{l}\text { Article history: } \\
\text { Received: } 20 \text { Oktober } 2020 \\
\text { Revised: } 26 \text { Oktober } 2020 \\
\text { Accepted: } 02 \text { November } 2020\end{array}$ & $\begin{array}{l}\text { Technical problems in the digital photography era have now been } \\
\text { overcome by the sophistication of cameras. The problem that } \\
\text { technology cannot solve is the composition of the image. } \\
\text { Composition is a skill that requires an understanding of }\end{array}$ \\
\hline $\begin{array}{l}\text { Keywords: } \\
\text { Landscape } \\
\text { Golden section } \\
\text { DSLR camera }\end{array}$ & $\begin{array}{l}\text { photographic objects, visual elements, and artistic experience. } \\
\text { Composition is related to the placement of objects and how to build a } \\
\text { flow of view in viewing photos that have an impact on the impression } \\
\text { of the photo. The decision to press the camera's shutter button is a } \\
\text { consideration of composition, and is not easily understood by } \\
\text { students or beginners who are just learning photography. So that } \\
\text { with knowledge of the composition of this golden section, } \\
\text { photographers can produce more optimal work. Careful at every } \\
\text { visual element that exists, skilled in arranging objects so that better } \\
\text { visuals are created. Super-sophisticated camera technology cannot } \\
\text { search for objects on its own, therefore this research is offered. The } \\
\text { Golden Section Theory has been successfully applied to the field of } \\
\text { architecture in the 5th century BC and in the field of painting during } \\
\text { the renessance era. In this study, the author tries to apply this } \\
\text { formula to determine the main object (center of attention) in a beach } \\
\text { scene photo in Gunungkidul in 2: } 3 \text { image format or the default } \\
\text { DSLR camera format. }\end{array}$ \\
\hline
\end{tabular}

\section{PENDAHULUAN}

Keindahan objek wisata alam pemandangan pantai di Gunungkidul telah tersohor ke seluruh penjuru dunia. Daerah ini memiliki pantai terjal dan landai dengan pasir putih yang indah. Pantai yang mempesona menyisakan persoalan dan tidak mudah untuk dipotret dengan sudut penataan komposisi gambar yang baik. Hasil foto dengan teknis pencahayaan (exposure) yang tepat begitu mudah di era digital ini. Sejumlah pekerjaan teknis sudah dilakukan oleh teknologi kamera, bukan lagi prestasi orang di belakang kamera. Banyak kendala yang dihadapi baik secara teknis dan non teknis yang perlu dipahami oleh fotografer untuk mendapatkan foto 
pantai yang baik. Kebiasaan untuk langsung memotret di posisi fotografer berdiri masih sering ditemukan. Hal ini diasumsikan karena ketidaktahuan dalam memahami objek foto dan pentingnya komposisi dalam sebuah foto. Wisatawan menggunakan kamera smartphone dan perekaman dilakukan atas dasar suka-suka dan belum memikirkan faktor keindahan sehingga hasil perekaman belum maksimal. Dengan alasan tersebut penelitian ini dilakukan, dengan tujuan memberikan solusi terhadap persoalan komposisi sehingga hasil foto menjadi lebih baik.

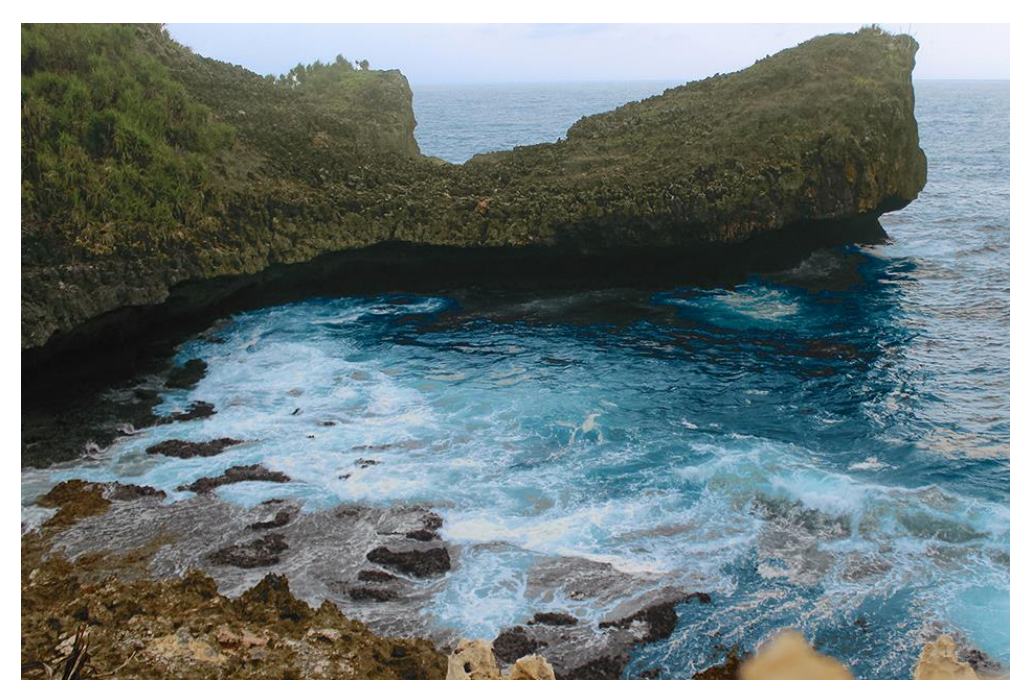

Gambar 1. Pemandangan Pantai Kasirat karya Husaini Ibrahim (Sumber: Foto karya Husaini Ibrahim, dokumentasi penulis)

Dari contoh foto di atas (Gambar. 1) terasa bahwa penempatan tebing yang menjorok ke laut di bagian atas terasa mengganggu, sehingga dapat disimpulkan bahwa dibutuhkan keterampilan fotografer untuk mengarahkan lensanya dan menangkap susunan objek-objek atau komposisi dengan baik, sehingga pengetahuan tentang sudut pandang pengambilan gambar atau komposisi menjadi penting diketahui. Fotografer dapat memanfaatkan teori "golden section" dan mengembangkannya sebagai acuan penempatkan objek utama, membangun alur pandang, mood dan daya tarik visual pada fotonya. Demikian penelitian ini akan membahas penerapan rumus komposisi tersebut pada foto-foto pantai di Gunungkidul.

\section{METODE PENELITIAN}

Penelitian ini merupakan penelitian kualitatif dengan pendekatan studi pengambilan gambar di lapangan sebagai data objek penelitian. Penentuan objek foto yang memiliki daya tarik visual pada objek utama dengan survei lapangan. Mengaplikasikan rumus golden section pada layar LCD kamera dan smartphone dengan media tembus pandang. Pengambilan gambar 
langsung di lokasi dengan pemilihan objek utama dan penempatannya di bidang gambar.

Penempatan objek utama di titik pusat rumah siput pada teori golden section.

Guna mencapai tujuan pengaplikasian teori ini maka penelitian ini dilakukan dalam beberapa tahap yang dirangkum dalam metode penelitian lapangan berupa: Persiapan yaitu pengkajian terhadap teori golden section. Efektivitas penggunaan teori ini pada format gambar dan asperical ratio yang tepat. Peneliti menganalisa format golden ration yang paling mendekati adalah format gambar mendatar (landscape) ukuran 2:3 efektif memperlihatkan kesan keluasan alam yang akan difoto. Berpedoman pada rumus kajian teori golden section sebagai acuan materi yang digunakan selama kegiatan penelitian ini.

Survey lokasi dan pengambilan data adalah penentuan objek foto dan lokasi pengambilan gambar mempertimbangkan ciri khusus lokasi yang mudah diingat. pengambilan data objek dan penelitian dilangsungkan. Analisa objek, proses analisa hasil observasi. Penentuan media yang tepat untuk mengaplikasikan teori ini dengan mika plastik bening di layar LCD di belakang kamera dan layar smartphone yang tidak mengganggu pengamatan pada objek foto. Aplikasi rumus golden section pada foto hasil survey yang memenuhi kriteria penempatan objek utama mendekati titik pusat lingkaran spiral pada rumus golden section.

Sample data terpilih berupa foto-foto yang sesuai dengan teori golden section dijadikan model, di cetak ukuran $5 \mathrm{R}$ glossy ditempel di atas karton tebal dan dibawa pada saat melakukan pengambilan gambar kedua. Rumus golden section yang telah ditempelkan pada LCD kamera dan layar smartphone digunakan untuk acuan pengambilan gambar foto pemandangan di Pantai Wahkodo, Pantai Wedhi Ombo, dan beberapa pantai di Gunungkidul. Pengambilan gambar mengunakan tripod dan mencatat kendala yang ditemukan selama proses pengambilan gambar berlangsung. Hasil penelitian berupa foto-foto pantai di Gunungkidul yang mengikuti teori komposisi golden section yang dapat dilihat pada hasil penelitian.

\section{PEMBAHASAN}

\subsection{Foto Pemandangan (Landscape Photography)}

Dalam buku Landscape and Nature yang ditulis oleh Michael Freeman (2004) foto pemandangan alam adalah natural landscape is representational a realistic. Foto keindahan alam yang merepresentasikan sebuah realitas dari alam. Kecenderungan kedua natural landscape is impressionistic, in which obvious detail is suppressed in favour of a nature atmospheric and evocative image. Ketiga Natural landscape photography is exploress abstract, graphic possibilities, also at the expense of recording all the details. foto landscape, menyajikan alam 
dalam impresi dan abstrak. Penelitian ini menerapkan konsep foto pemandangan yang natural dan mampu mendefinisikan lokasi dengan baik (Freeman, 2004). Di dalam dunia fotografi sebagai ekspresi murni telah dilakukan oleh Ansel Easton Adams pada pemandangan alam di Taman Nasional Yosemite, Amerika Serikat dan tetap mempertahankan identitas lokasi dengan kuat. Adams menggunakan diafragma terkecil untuk ketajaman optimal, ia juga menggunakan picture format yang 2:3 yaitu frame format standar untuk kamera Single Lens Reflexs (SLR) di era konvensional (Turnage, 1980).

\subsection{Golden Section}

Golden section merupakan salah satu dari penemuan terbesar dalam ilmu geometri yang disebut juga golden ratio. Golden ratio adalah istilah dalam ilmu matematika untuk kondisi dimana jumlah kedua angka dibagi angka A sama dengan angka A dibagi angka B, dimana $\mathrm{A}>$ B. Golden ratio sering digambarkan sebagai angka keindahan. Salah satu konsep pendekatan untuk menerangkan perbandingan ideal dalam menciptakan keindahan komposisi.

Golden ratio ditemukan oleh Phidias pematung hebat asal Yunani pada abad sebelum masehi, kemudian ditemukan dalam karya Plato dan di abad selanjutnya didefinisikan oleh Euclid dan disebut dengan "extreme and mean ratio". Ketika Perikles berkuasa di Athena, Phidias ditunjuk untuk mengatur seni, arsitektur dan patung Athena. Salah satu hasil karya Phidias di Parthenon yaitu Athena Parthenos dan mengandung Golden ratio.

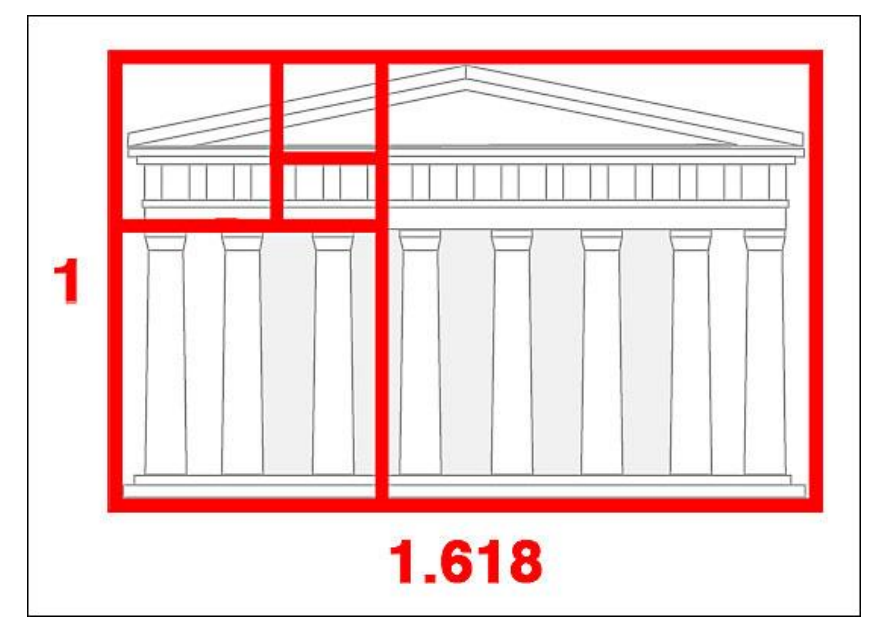

Gambar 2. Penerapan golden ratio pada parthenon didapat dengan penelitian, jadi bangunan parthenon sudah ada sebelum ditemukannya golden ratio pada abad ke-5 SM. (Sumber: Dokumentasi penulis)

Pada bangunan Parthenon, penerapan golden ratio digunakan berdasarkan bentuk bidang persegi untuk mendapatkan perbandingan yang ideal. Sehingga bangunan memiliki ukuran yang dapat dijelaskan berdasarkan golden ratio. Tinggi bangunan pada Parthenon merupakan lebar 
bangunan yang telah di bagi dengan $\varphi$ (phi). Seandainya lebar bangunan merupakan 1,618, maka tingginya adalah $1,618 / \varphi=1$. Sedangkan untuk tinggi kolom merupakan tinggi bangunan yang telah dibagi dengan $\varphi$, yaitu $1 / \varphi=0,61804697$ atau 0,618 .

Faktanya tinggi Parthenon adalah 20 meter dan panjangnya adalah 32,36 meter. Apabila panjang bangunan tersebut dibagi dengan $\varphi$ (phi) yaitu 32,36 meter: 1,618 maka hasilnya adalah 20 meter yang tak lain adalah tinggi dari bangunan Parthenon. Selanjutnya tinggi kolom merupakan tinggi bangunan dibagi dengan $\varphi$ (phi) yaitu 20 meter: 1,618 maka hasilnya adalah 12,36 meter (Akhtaruzzaman \& Shafie, 2012). Teori Golden section telah terbuki dapat digunakan untuk merumuskan penempatan objek-objek dan hasilnya dapat dikatakan susunan yang indah.

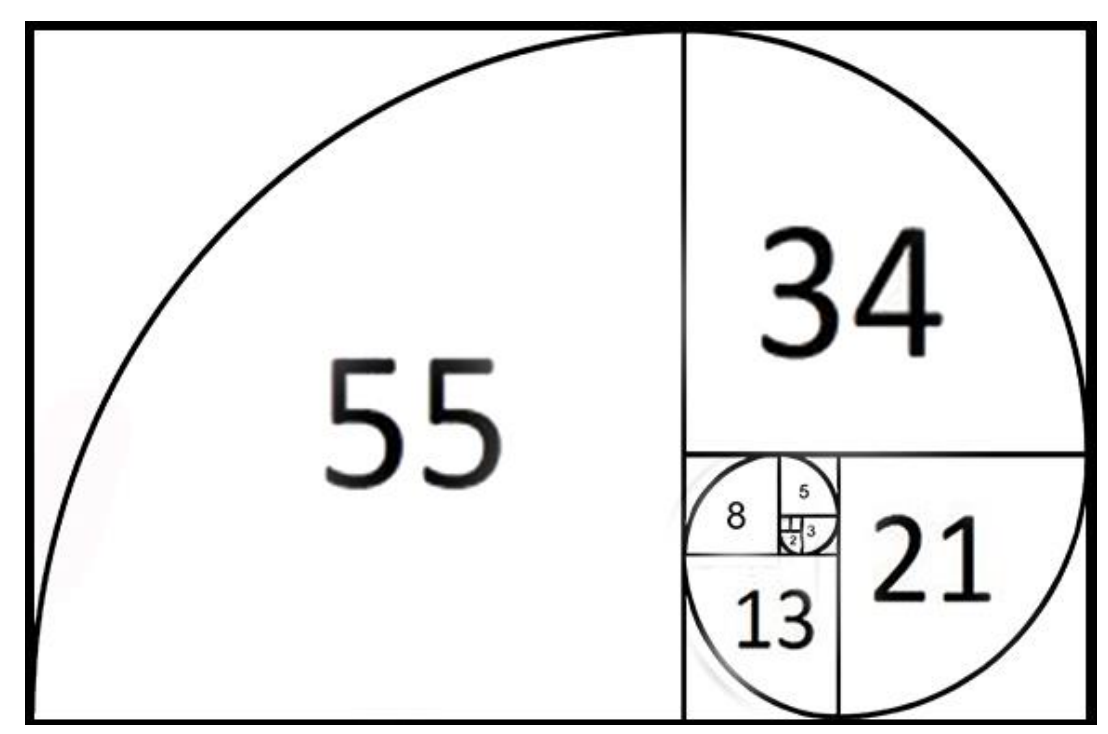

Gambar 3. Rumus Golden section atau irisan keemasan dalam luas bagian bidang.

(Sumber: Dokumentasi penulis)

Teori golden section ini akan peneliti gunakan untuk menentukan komposisi foto landscape pantai di Kabupaten Gunungkidul. Penulis berasumsi teori ini dapat diterapkan pada komposisi fotografi, khususnya objek pantai dan akan menghasilkan foto landscape pantai yang berkarakter.

\subsection{Kamera Digital}

Kamera Digital Single Lens Reflexs (DSLR) adalah kamera refleks lensa tunggal yang memiliki pentaprisma/pentamirror yang membantu memproyeksikan benda (objek) yang diamati masuk melewati lensa (through the lens) dipantulkan ke mata pengamat. Pengamat kemudian 
menekan tombol shutter, maka kaca (mirror) yang diletakkan miring 45 derajat di dalam kamera akan terangkat dan permukaan film/ sensor digital akan tercahayai (ter-expose) dan menyimpan bayangan objek (image) dengan sempurna. Pada era konvensional disebut Single Lens Reflexs (SLR). Pertama kali diciptakan bangsa Jerman dengan format 135 yang praktis dibawa berpergian. Kamera ini memiliki sistem fokus untuk mengatur ketajaman objek dalam titik fokus yang dapat diatur secara otomatis dan manual. Kamera DSLR juga dilengkapi dengan metering system yang membantu fotografer untuk menentukan pengukuran cahaya yang diharapkan. Kamera ini juga memiliki komponen penentu exposure yaitu ISO/ASA yang menentukan tingkat kehalusan butiran gambar yang akan dihasilkan. Shutter speed untuk membatasi lamanya waktu pencahayaan pada setiap fotograferan dan diafragma (apperture) untuk menentukan besaran bukaan lensa untuk meloloskan cahaya hingga ke film/ CCD. Diafragma juga berfungsi untuk menentukan jarak fokus area pada objek. Ketiga komponen ini saling bersinergi untuk menghasilkan kualitas gambar (foto) yang baik. Kamera ini unumnya dimiliki oleh penggemar fotografi sehingga menjadi alasan bagi penulis untuk menggunakannya pada penelitian ini.

Secara performa kamera DSLR cukup baik dalam menghasilkan kualitas gambar. Teknologi kamera digital saat ini dilengkapi dengan fasilitas grid system untuk membantu fotografer mengatur penempatan komposisi objek foto, namun banyak diantara pengguna kamera DSLR bahkan tidak tahu bagaimana mempergunakan grid system tersebut secara optimal. Dengan memahami teori rule of thirds, grid system pada kamera DSLR ini dapat di pergunakan sebagai garis yang membantu peletakan objek utama dan garis cakrawala pada foto pemandangan pantai. Rule of thirds merupakan aturan sepertiga yakni rumus komposisi yang paling populer (Adharul \& Aswin, 2014). Rule of thirds membagi area bidang gambar menjadi sembilan bagian yang sama besar sedangkan golden section berbentuk irisan melingkar. Kamera digital perlu dipahami sistem kerjanya sehingga automatic exsposure system dan manual system pada kemera ini dapat dioptimalkan untuk merekam objek foto pantai.

Kamera DSLR memiliki metering system yang berfungsi untuk membaca pencahayaan dan menentukan nilai exposure. Pengukuran ini dibutuhkan untuk membaca pencahayaan pada objek foto alam dengan available lighting. Fitur ini bekerja sesuai dengan jenis metering yang di pilih oleh fotografer dan untuk foto landscape dipasang pada posisi cahaya rata-rata atau average (Iqbal et al., 2016).

\subsection{Penerapan Rumus Golden Section Pada Layar Smartphone dan Kamera DSLR}

Plastic mika bening yang tebal direkatkan pada layar smartphone. Rumus ini akan 
menuntun fotografer untuk menempatkan objek utama pada titik pusat lingkaran spiral. Plastik mika bening ini dapat di putar (rotate) ke kanan dan ke kiri. Juga dapat di balik (flip) berlawanan arah atas bawah dan kiri kanan sesuai kebutuhan.

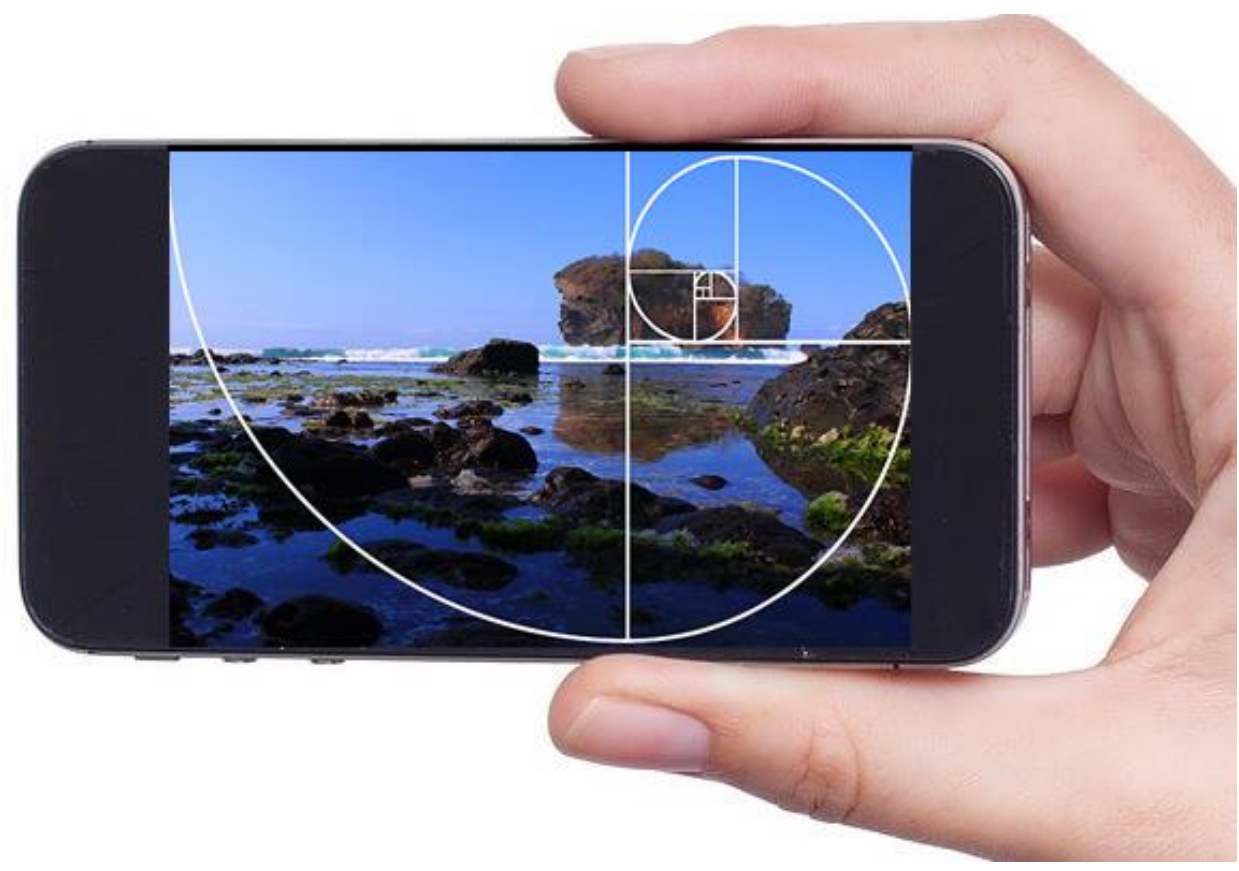

Gambar 4. Aplikasi rumus golden section pada layar smartphone

(Sumber: Dokumentasi penulis)

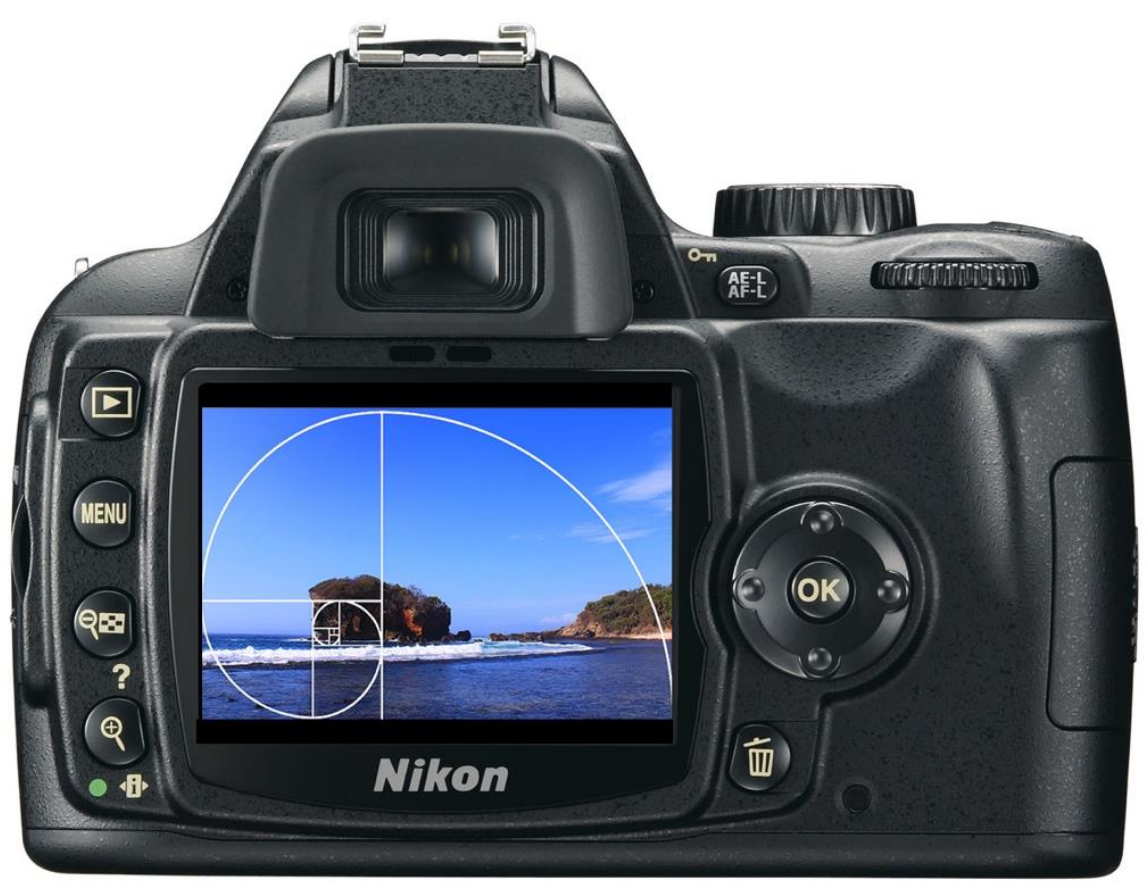

Gambar 5. Aplikasi rumus golden section pada layar DSLR camera.

(Sumber: Dokumentasi penulis) 
Peneliti berharap dapat menemukan sebuah formulasi dalam meneliti atau acuan yang dapat dipergunakan sebagai pedoman dalam pembuatan foto pemandangan pantai di Kabupaten Gunungkidul secara optimal. sekaligus mempopulerkan golden section untuk foto pemandangan pantai.

Penelitian ini diawali dengan survei, penentuan lokasi, sudut pandang dan waktu pengambilan gambar. Penerapan teori golden section dilakukan pada objek pemandangan pantai langsung di lokasi. Hasil foto kemudian dianalisa melalui komputer di kampus STSRD VISI. Penelitian ini diharapkan dapat menemukan faktor-faktor lain yang ikut mempengaruhi keindahan tampilan foto lanscape pantai di Kabupaten Gunugkidul.

\subsection{Hasil Penelitian}

Tingkat keberhasilan penerapan rumus komposisi golden section pada foto pemandangan pantai ditinjau dari aspek ketepatan dalam penempatan objek utama di posisi titik pusat rumus golden section yang ditempelkan di layar LCD kamera. Pengetahuan terhadap objek foto mempertimbangkan daya tarik sebuah pemandangan pantai untuk difoto. Jika punya daya tarik bagaimana penempatan pusat perhatian utama dan dimana penempatannya.

Hasil penelitian ini diambil dengan menggunakan kamera DSLR dan kamera smartphone. Seting kamera DSLR sebagai pendukung kualitas hasil foto yang pemandangan pantai baik. Resolusi tinggi mengunakan Jpeg fine, ISO rendah 100/200, Mode berwarna (colorday light). Pengaturan Kamera smartphone beresolusi 12 mega pixel. Aktifkan fitur profesional, menggunakan ISO rendah untuk hasil yang maksimal. Faktor lain yang berpengaruh terhadap hasil pantai yang bagus. Faktor pencahayaan, karena cahaya menghidupkan kesan suasana pada foto landscape.

Berikut ini contoh foto yang kurang optimal karena mengabaikan faktor pencahayaan, kesalahan mengatur asperical ratio, penempatan objek utama yang tidak tepat, objek kurang layak untuk difoto. Pertimbangan besaran tampilan objek utama pada frame, ketidak telitian fotografer sehingga masuknya objek lain mengganggu komposisi. 


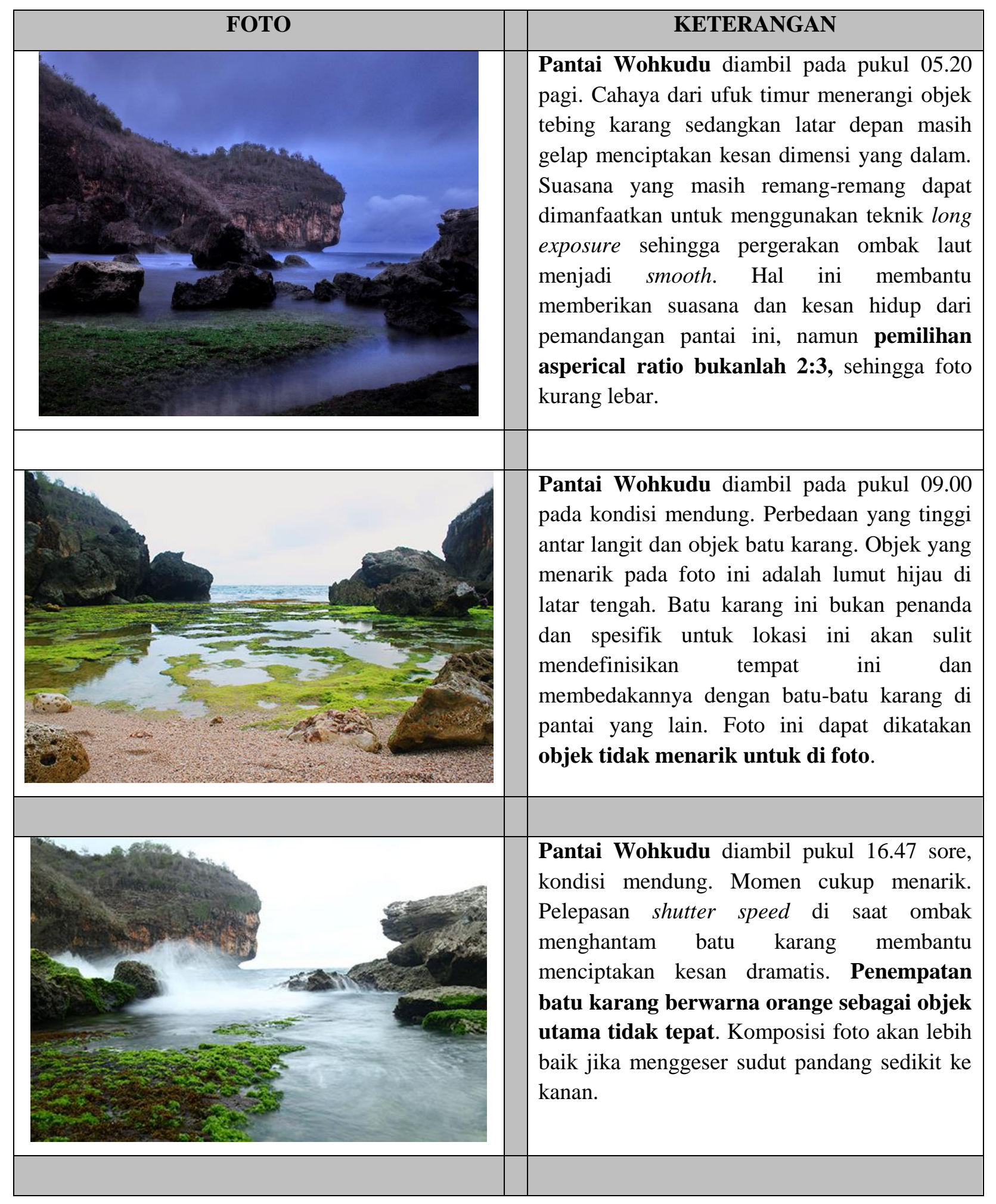




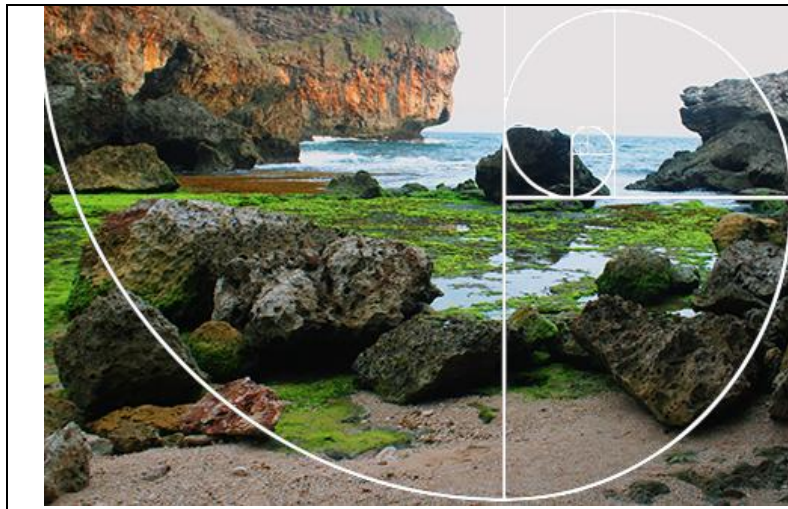

Pantai Wohkudu di foto ini pemilihan dan penempatan objek batu karang hitam dan tidak terkena cahaya, tidak memiliki detail tidak menarik untuk dijadikan objek utama. Objek utama dengan warna dan detail yang jelas lebih menarik untuk dijadikan objek utama dan ditempatkan di titik strategis. Artinya pemilihan objek utama pada foto ini kurang tepat, walaupun penempatannya di titik pusat rumah keong pada rumus golden section.

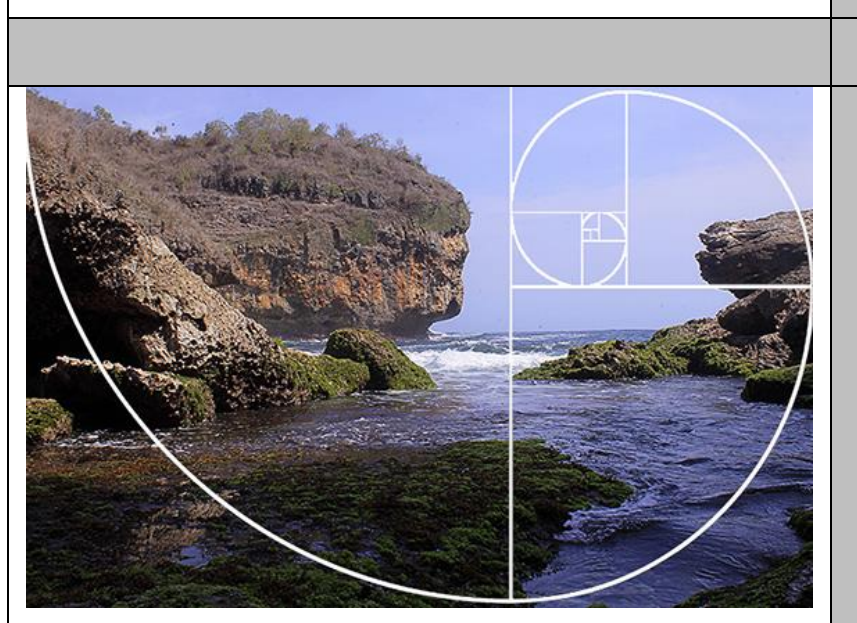

Pantai Wohkudu, adanya cahaya matahari yang menerangi objek ini menjadikan warnanya muncul baik. Bila diperhatikan komposisi foto ini memiliki kekurangan yaitu Penempatan batu karang berwarna orange tidak menyinggung titik pusat rumah keong pada rumus golden section.

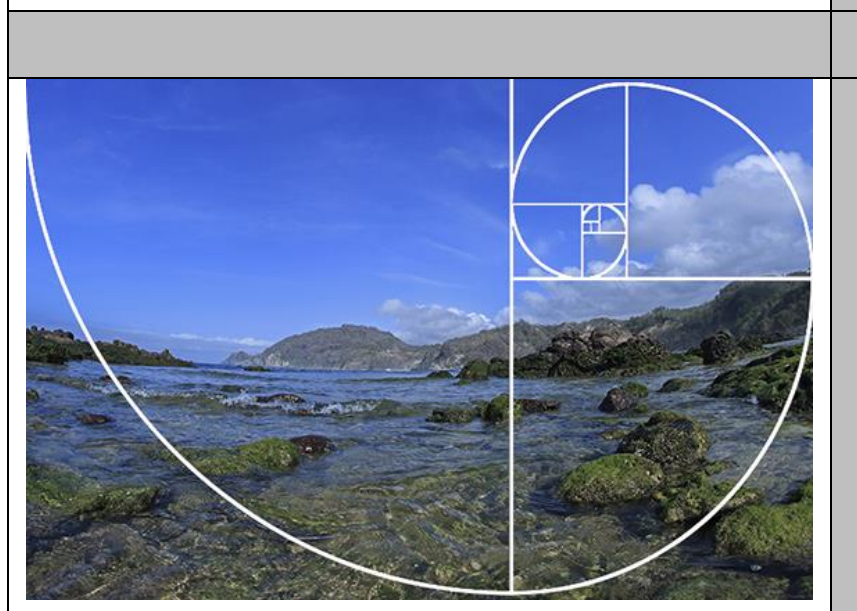

\section{Pantai Wedhi Ombo}

Foto ini memperlihatkan objek utama yang lemah. Informasi mengenai ciri khas dari pantai ini tidak terekpos dengan baik. Pemirsa juga akan sulit menduga dimana lokasi pengambilan gamabr untuk foto ini.

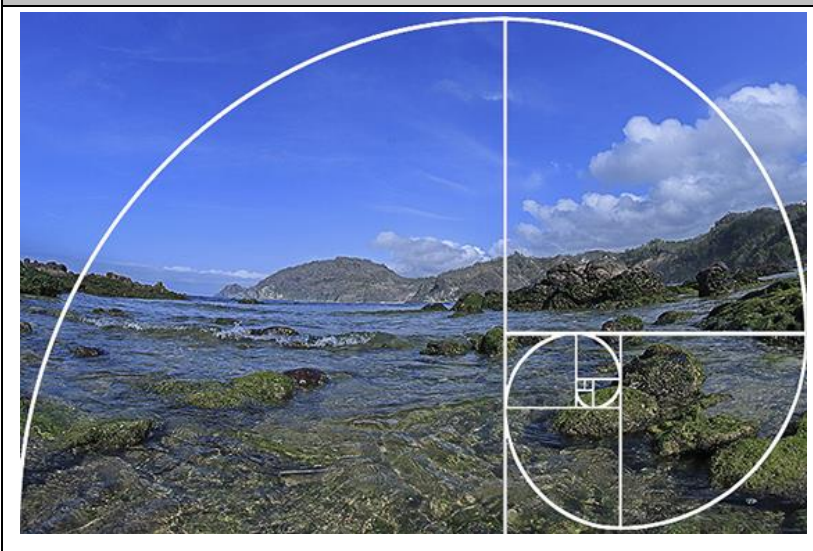

Pantai Wedhi Ombo rumus golden section di flipe vertical mengenai batu berlumut di bagian depan yang tidak begitu menonjol secara warna dan keunikan. Penempatan rumus golden section pasca pengambilan gambar atau di layar komputer tidak efektif. Sensasi merasakan komposisi terjadi saat pengambilan gambar adalah hal utama dari penelitian ini. Jika di kroping di komputer membuang bagian gambar terlalu banyak dan megurangi kualitas foto. 


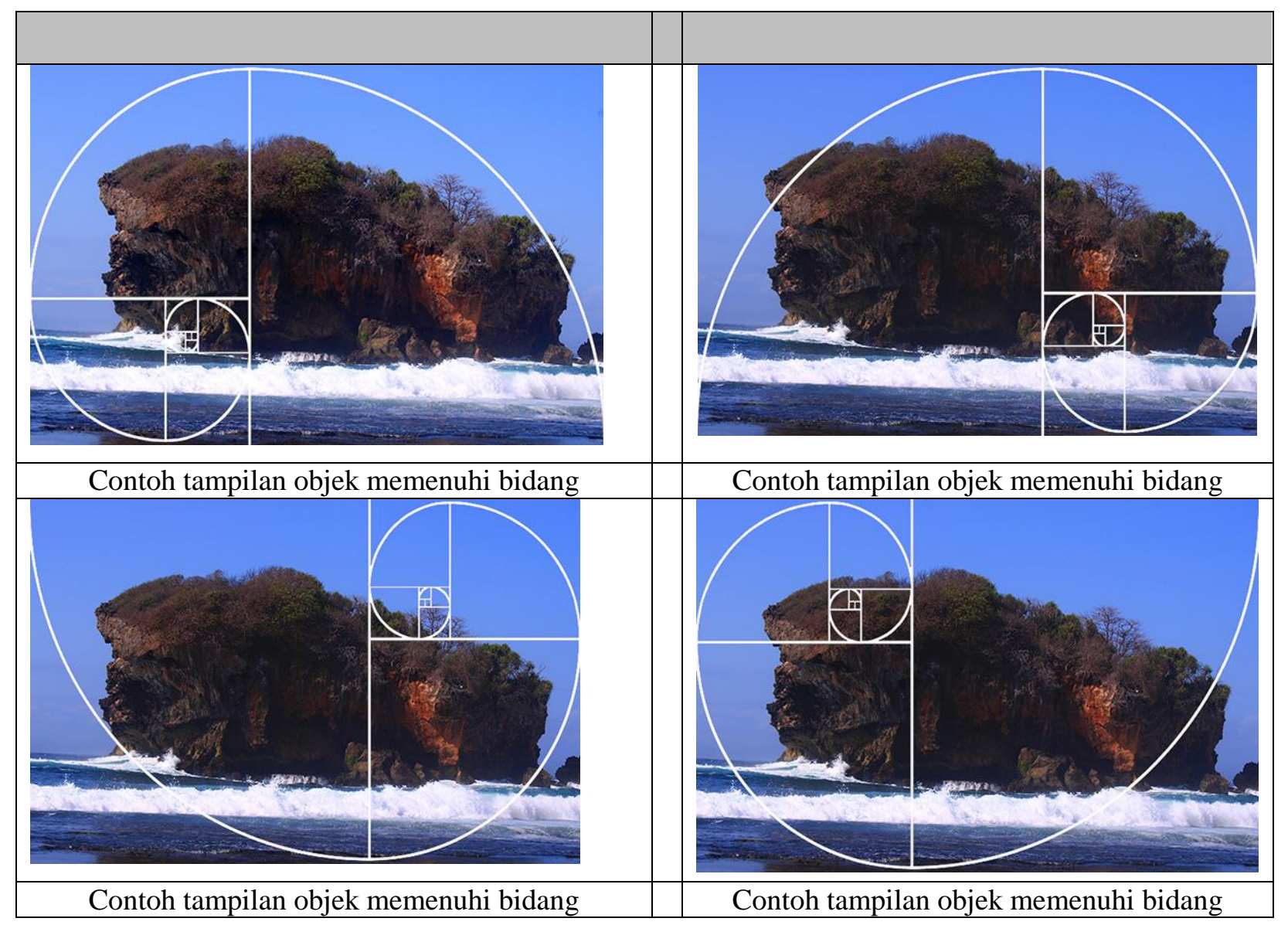

Hasil fotograferan dengan menerapkan rumus "golden section" dan pembahasan.

\begin{tabular}{|l|l|l|}
\hline \multicolumn{2}{|c|}{ Rumus golden section } & \multicolumn{1}{|c|}{ Keterangan } \\
\hline & & $\begin{array}{l}\text { Garis lengkung spiral menyerupai rumah } \\
\text { keong ini di print di atas selembar plastik } \\
\text { mika yang agak tebal dan kaku. Sehingga } \\
\text { tidak menganga pandang ke layar LCD } \\
\text { kamera atau layar LCD smartphone. Rumus } \\
\text { ini dibuat sebesar layar LCD alat rekam } \\
\text { gambar dan dapat diputar flipe kiri-kanan dan } \\
\text { atas-bawah. Penempatan rumus ini membantu } \\
\text { menempatan objek utama pada layar LCD } \\
\text { dengan menggeser posisi objek ke titik pusat } \\
\text { dari garis lengkung ini. }\end{array}$ \\
\hline
\end{tabular}




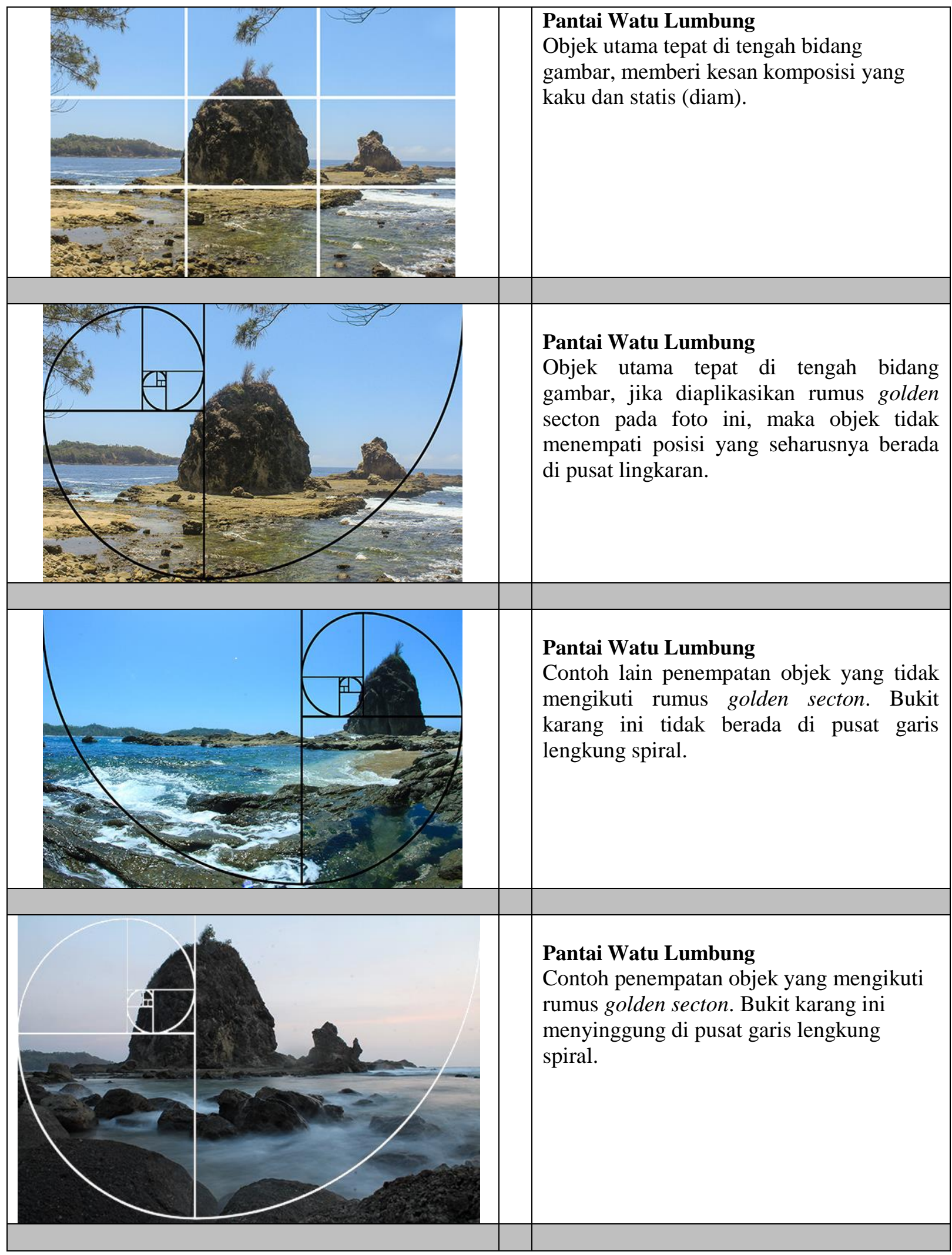


Posisi Objek Utama Mengikuti Rumus Komposisi Golden Section.

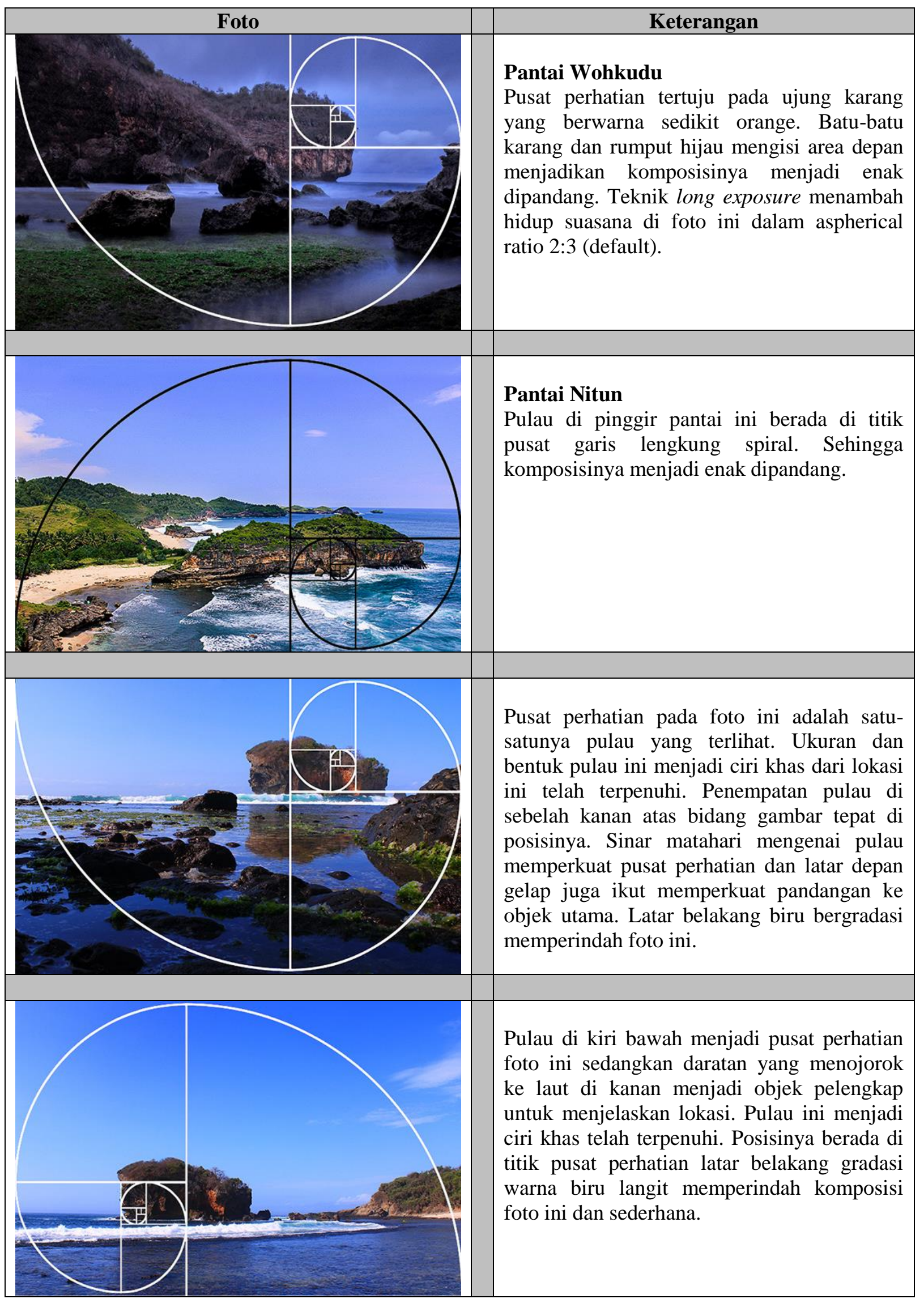




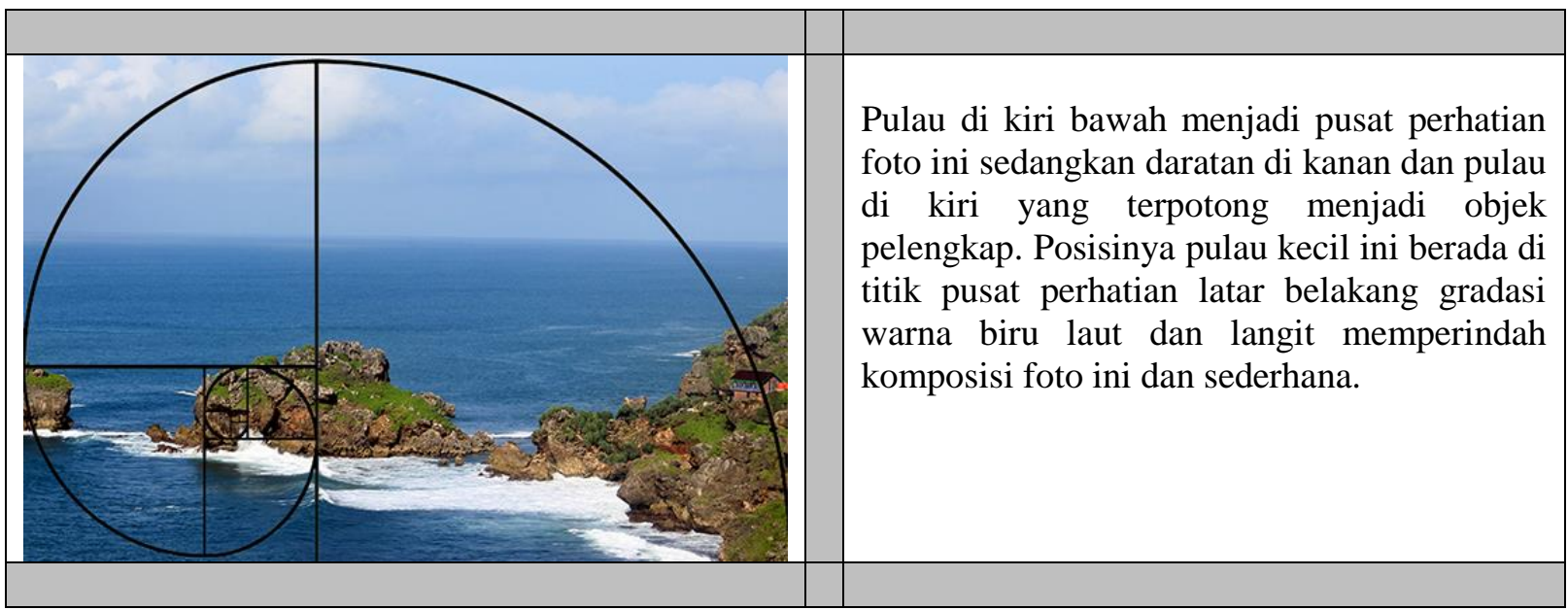

Persoalan yang sulit dipecahkan secara instan di dalam komposisi fotografi. Teknologi kamera belum dapat mengatasi persoalan komposisi dari dulu hingga sekarang. Hal ini disebabkan karena kasus yang dihadapi saat pengambilan gambar sangat beragam dan belum tentu sama dapat diselesaikan dengan satu teori. Komposisi merupakan keterampilan fotografer dalam memahami objek foto, elemen visual dan menempatan objek di dalam bidang gambarnya. Komposisi berpengaruh terhadap kemasan pesan yang akan disampaikan melalui sebuah foto. Mata diarahkan pada pusat perhatian yang diletakkan di pusat lingkaran kemudian baru ke tempat lain di dalam sebuah foto. Strategi membangun alur pandang melihat foto ini berdampak pada aspek psikologis audiens. Banyak teori terkait komposisi foto, namun komposisi seperti apa yang akan digunakan merupakan keputusan fotografer. Walaupun pengaruh cita-rasa dan pengalaman ikut menentukan hasil foto.

Keputusan menekan tombol rana kamera adalah keputusan pengambilan komposisi. fotografer pemula merasa sulit memahami komposisi fotografi kerena membutuhkan wawasan dan pengetahuan lain yang berhubungan dengan objek foto, warna, tata cahaya dan elemenelemen visual. Padahal kasus yang ditemukan di lapangan tidak selalu sama dengan contoh yang ujicobakan sebagai penerapan teori-teori komposisi yang ada. Guna mempercepat pemahaman terhadap komposisi fotografi tersebut hasil penelitian teori golden section ini layak untuk dicoba dipraktekkan.

\section{KESIMPULAN}

Keterampilan fotografer dalam menciptakan komposisi fotografi tidak diperoleh secara instan, melainkan melalui latihan yang dilakukan secara terus-menerus. Penelitian ini dapat membantu pemahaman fotografer pemula dalam melatih keterampilannya memahami komposisi foto. Dengan pengetahuan komposisi golden section ini, fotografer dapat menghasilkan karya 
yang lebih optimal, dan melihat dengan cermat setiap elemen visual yang ada dalam jendela bidik kamera untuk disusun sehingga tercipta visual yang lebih baik.

Peneliti membuktikan bahwa teori golden section dapat membantu penempatan objek utama di dalam camera frame dan memberi kesan dinamis dan kenyamanan. Solusi merekatkan rumus golden section di LCD kamera (alat rekam) untuk sementara dapat digunakan. Garis lengkung dan titik pusat pada rumus ini dapat dipergunakan untuk membantu menempatkan pusat perhatian foto. Posisi objek akan berada di titik strategis pada format 2:3. Metode ini digunakan untuk mendapatkan komposisi foto landscape pantai di Gunungkidul yang lebih baik.

Teori golden section sudah lama diketahui dan digunakan di bidang arsitektur, namun penerapannya di bidang gambar (foto) dengan cara menempelkan langsung rumus ini pada layar LCD kamera atau di layar smartphone belum pernah dilakukan. Melalui penelitian ini dapat dipetakan kesiapan pengaplikasian rumus ini dan diketahui status kesiapan metode ini sebagai solusi penyelesaian masalah komposisi dalam fotografi sehingga hasilnya dapat digunakan untuk mengaplikasikan teori golden section dalam menciptakan komposisi foto yang baik.

\section{DAFTAR PUSTAKA}

Adharul, \& Aswin. (2014). Penilaian Komposisi Rule of Thirds Pada Fotografi Menggunakan Bantuan Pengolahan Citra Digital. Jurnal Mahasiswa Teub.

Akhtaruzzaman, M., \& Shafie, A. A. (2012). Geometrical Substantiation of Phi, the Golden Ratio and the Baroque of Nature, Architecture, Design and Engineering. International Journal of Arts. https://doi.org/10.5923/j.arts.20110101.01

Freeman, M. (2004). Landscape and Nature. Prigel books.

Iqbal, M., Widodo, T. W., \& Sumbodo, B. A. A. (2016). Sistem Pengendali Pengambilan Gambar Pada Kamera DSLR Melalui Protokol PTP. IJEIS (Indonesian Journal of Electronics and Instrumentation Systems). https://doi.org/10.22146/ijeis.15248

Turnage, R. (1980). Ansel Adam: The Role of the Artist in the Environment. http://www.205.178.161.74/content/ansel_info/conservation.html 